\title{
CLIMATE RISK IN MAIZE CROP IN THE NORTHEASTERN OF BRAZIL BASED ON CLIMATE CHANGE SCENARIOS
}

\author{
VICENTE DE P. R. DA SILVA ${ }^{1}$, JOÃO H. B. DA C. CAMPOS ${ }^{2}$, MADSON T. SILVA ${ }^{3}$
}

\begin{abstract}
This study evaluates the impacts of climate change on the agricultural zoning of climatic risk in maize crop cultivated in the Northeastern of Brazil, based on the Intergovernmental Panel on Climate Change (IPCC) reports. The water balance model, combined with geospatial technologies, was used to identify areas of the study region where the crops could suffer yield restrictions due to climate change. The data used in the study were the time series of rainfall with at least 30 years of daily data, crop coefficients, potential evapotranspiration and duration of the crop cycle. The scenarios of the increasing of air temperature used in the simulations were of $1.5^{\circ} \mathrm{C}, 3^{\circ} \mathrm{C}$ and $5^{\circ} \mathrm{C}$. The sowing date of maize crop from January to March appears to be less affected by warming scenarios than the sowing in November and December or April and May.
\end{abstract}

KEYWORDS: Global warming, water balance, rainfall, agricultural zoning.

\section{RISCOS CLIMÁTICOS PARA O MILHO NO NORDESTE DO BRASIL COM BASE EM CENÁRIOS DE MUDANÇA DO CLIMA}

RESUMO: Este estudo avalia os impactos das alterações climáticas sobre o zoneamento agrícola de risco climático do milho cultivado na região Nordeste do Brasil, com base nos relatórios do IPCC (Intergovernmental Panel on Climate Change). O modelo de balanço hídrico, combinado com técnicas de geoprocessamento, foi utilizado para identificar as áreas da região de estudo onde a cultura poderá sofrer restrições de rendimento devido à mudança do clima. Os dados utilizados no estudo foram as séries históricas de precipitação, com no mínimo 30 anos de dados diários, coeficientes de cultura, evapotranspiração potencial e a duração do ciclo da cultura. Os cenários de aumento na temperatura do ar utilizados nas simulações foram de 1,$5 ; 3,0$ e 5,0 ${ }^{\circ} \mathrm{C}$. A época de semeadura, de janeiro a março, da cultura de milho é menos afetada pelos cenários de aquecimento do que a semeadura nos meses de novembro e dezembro ou de abril e maio.

PALAVRA-CHAVE: Aquecimento global, balanço hídrico, precipitação, zoneamento agrícola.

\section{INTRODUCTION}

The anthropogenic interference with the environment, with the increasing global atmospheric concentrations of carbon dioxide (currently around 400ppm), methane and nitrous oxide from the beginning of the Industrial Revolution, has caused considerable changes in the Earth's climate (SILVA, 2004). Besides the systematic reports presented by the Intergovernmental Panel on Climate Change (IPCC), the importance of this issue for the survival of living species on our planet has motivated many discussions in the scientific field with the publication of several papers dealing on climate change in different parts of the world (CAMPOS et al., 2010; SILVA et al., 2010a).

Climate change impacts on natural ecosystems, and specifically in the distribution of biomass, which has impacts on biodiversity, agriculture and water resources. Thus, the impacts of climate change in agriculture can add even greater challenges to ensuring growth and development of food security and poverty reduction (SILVA et al., 2010a). Changes in covering and land use induce effects on the weather patterns and regional climate, which associated with plant response, affects

\footnotetext{
${ }^{1}$ Professor, Doutor em Recursos Naturais, UACA/CTRN/Universidade Federal de Campina Grande.

${ }^{2}$ Professor, Doutor em Recursos Naturais, Universidade Estadual da Paraíba.

${ }^{3}$ Doutorando em Meteorologia, UACA/CTRN/Universidade Federal de Campina Grande.

Recebido pelo Conselho Editorial em: 3-11-2011

Aprovado pelo Conselho Editorial em: 25-6-2012
} 
agricultural productivity. Some evidence of climate change can be detected by changes in radiation, rainfall and air temperature (SILVA et al., 2006).

ASSAD et al. (2004) simulated the impact of the increase in mean air temperature of $1^{\circ} \mathrm{C}, 3^{\circ} \mathrm{C}$ and $5.8^{\circ} \mathrm{C}$ and a $15 \%$ increase in rainfall in the potential of Brazilian coffee planting, set by the current agroclimatic zoning of coffee in the states of Goiás, Minas Gerais, São Paulo and Paraná. Also analyzing scenarios of increased air temperature set by the IPCC, CAMPOS et al. (2010) evaluated the impacts of global warming based on IPCC reports in agricultural zoning of climate risks for the cowpea crop, cultivated in dryland system in the state of Paraíba. In a most detailed and comprehensive study, SILVA et al. (2010a) analyzed the effects of climate change on the same crop for the Northeastern of Brazil and recommended that bean varieties more resistant to high temperatures should be developed with a view to global warming.

Other research has been presented on the effects of global warming on the productivity of different crops in Brazil: wheat, soybeans and maize (STRECK \& ALBERTO, 2006), coffee (GHINI et al., 2008), red rice (LAKE et al. 2008), perennial crops (GONDIM et al., 2008) and potato tubers (FAGUNDES et al., 2010).

In Brazil, maize is cultivated in all regions of the country, occupying an area of approximately 13 million hectares, with an average yield of 3,500 $\mathrm{kg} \mathrm{ha}^{-1}$ (CONAB, 2008). Besides being used for human consumption, this grain is considered standard plant for silage, by producing high quality silage and reduced losses (SALAZAR et al., 2010). However, with the increase of air temperature in the Northeast Region of Brazil, particularly in the semiarid region, many crops that are still grown in dryland system may have reduced their cultivated area, or even disappeared and thereby aggravate the poverty of the population.

Thus, it is necessary to undertake studies to assess the impacts of climate change on dryland farming in this region. In this context, considering that the increase of the world population must be accompanied by food production, and that knowledge of the various factors that affect agricultural production has great socioeconomic importance, the aim of this study was to analyze the possible influence of climate change suggested by IPCC in area of maize crop cultivated in dryland system in Northeast of Brazil.

\section{MATERIAL AND METHODS}

The Northeastern of Brazil covers an area of approximately 1.5 million square kilometers. The semiarid part corresponds to approximately $60 \%$ of the total area of this region. This extensive area is inhabited by over 30 million people and the economy is based mainly on dryland agriculture. The Brazilian Northeast is greatly affected by anthropogenic activities because presents many degraded areas mostly in the semiarid part (SILVA et al., 2010b). This region is highly vulnerable to climate variability and frequencies of droughts that specifically affect subsistence farming (SANTOS et al., 2010). The Northeast semiarid area is characterized by low rainfall and high evaporation rates (SILVA et al., 2004).

The average annual rainfall varies from $1,800 \mathrm{~mm}$ in the east coast to $400 \mathrm{~mm}$ in the semiarid center, while the air temperature ranges from $16.8{ }^{\circ} \mathrm{C}$ to $33.8^{\circ} \mathrm{C}$ and evaporation can exceed $10 \mathrm{~mm} \mathrm{~d}^{-1}$ (SILVA et al., 2006 ). The predominant vegetation type is caatinga and the soil is very diverse, formed mostly of sandy Latosols (SILVA et al., 2010c). This study used data with at least 30 years of 665 rainfall stations in the analysis of climate risk for maize crop cultivated in the Northeast of Brazil in dryland conditions, which spatialization is shown in Figure 1. 


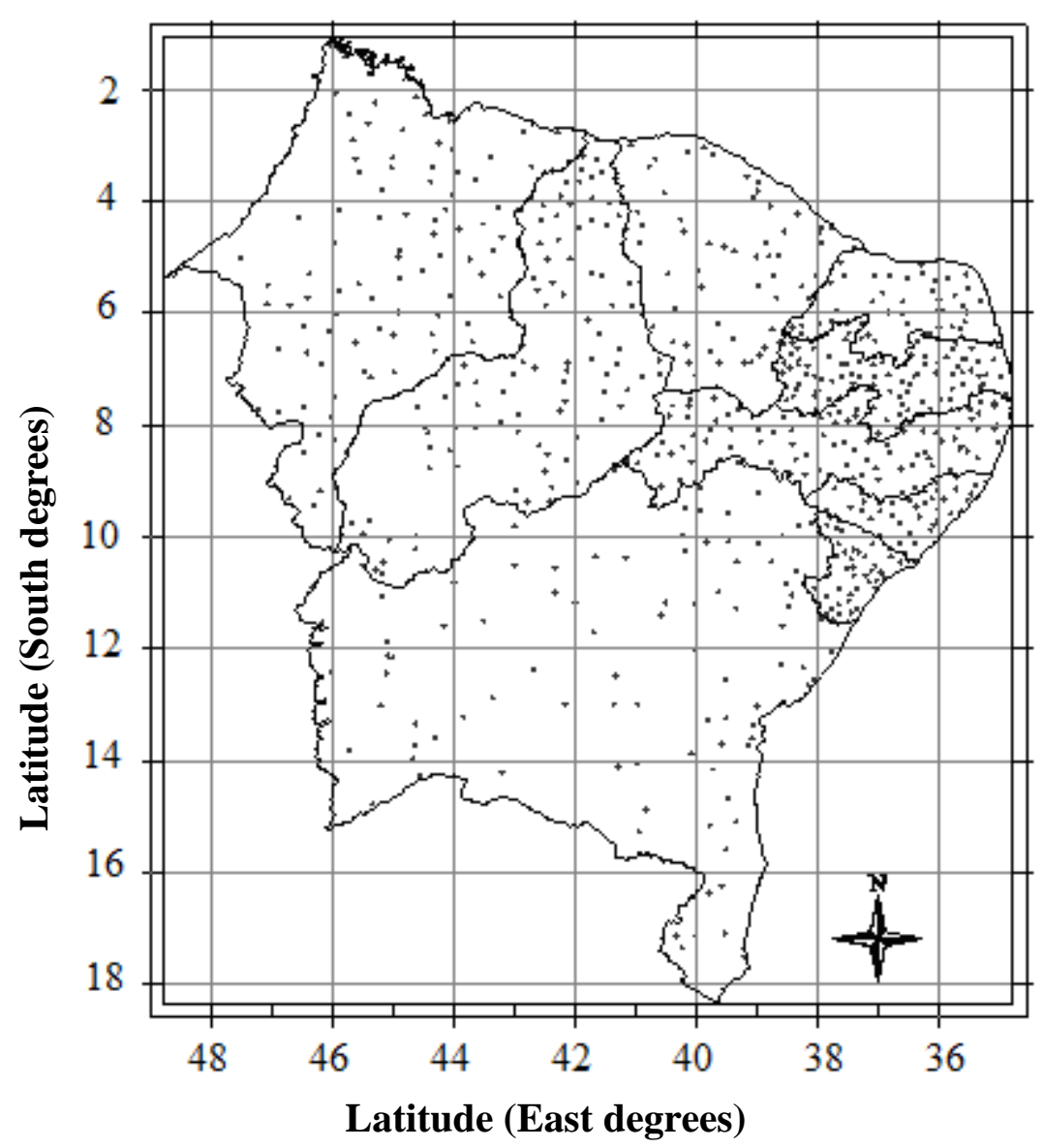

FIGURE 1. Map of the Northeastern of Brazil showing the location of the weather stations used in the study.

The climate risk condition was performed through a water balance model of culture, performed in two parts. At first, the water balance was determined assuming current conditions of air temperature and even scenarios of increased temperature of $1.5^{\circ} \mathrm{C}, 3^{\circ} \mathrm{C}$ and $5^{\circ} \mathrm{C}$ presented by IPCC (2007). It was determined the simulation of sowing dates, using the System of Regional Analysis of Agroclimatic Risks based on SARRAZON software (BARON et al., 2005). This software estimated water balance components of a vegetated surface in stratified soil using daily data of rainfall and potential evapotranspiration, beyond the crop coefficient, which describes the growth of crops and soil characteristics. In this model, the infiltration and redistribution of water in the soil is governed by Darcy-Buckingham equation and the actual evapotranspiration is obtained as a function of maximum evapotranspiration and soil humidity.

In the second part, it was used the values of WRSI (Water Requirement Satisfaction Index) estimated for all phenological periods of crop, with a minimum frequency of $80 \%$ in the years used in every season rainfall. Each WRSI value, observed during each phase, was associated with geographic location of their station for further spatialization, using the SPRING software, version 4.2.

The SARRA model (Systeme d'Analyse Regionale des Risques Agroclimatiques) is a relatively simple tool used at regional scales to assess the risks and impacts of agricultural drought. As a deterministic simulation model, it is used to establish zoning and climate risk analysis of cereals. This model can be performed in daily time scale (KOURESSY et al., 2008) and for the analysis of climatic impacts on growth and productivity of grains in tropical environments (BARON et al, 2005). It contains a simple model of soil water balance, which is used for the water requirement satisfaction index (WRSI), which represents the ratio of actual evapotranspiration $(\mathrm{ETa})$ and maximum evapotranspiration $(\mathrm{ETm})(\mathrm{WRSI}=\mathrm{ETa} / \mathrm{ETm})$. 
This index was originally developed by the Food and Agriculture Organization of the United Nations (FAO) to assess crop yields in regions with limited water. This index expresses the relationship between the amount of water consumed by the plant and the amount that would be desirable to ensure its maximum productivity.

The water content of the soil was measured using water balance in time increments of 10 days, assuming that the effective precipitation is $100 \%$ of the actual precipitation. The model requires as input data precipitation, evaporation, crop coefficient, water holding capacity of the soil, sowing date and depth of the root system. In this study, four values of water holding capacity of the soil were used according to the predominant soil texture of the area: $40 \mathrm{~mm} \mathrm{~m}^{-1}$ for sandy soils, $50 \mathrm{~mm} \mathrm{~m}^{-1}$ for sandy loam soils, $60 \mathrm{~mm} \mathrm{~m}^{-1}$ for silty clay soils and $7 \mathrm{~mm} \mathrm{~m}^{-1}$ for clay soils. A polynomial equation as a function of maximum evapotranspiration and soil humidity was used to obtain the actual evapotranspiration according to the model proposed by EAGLEMAN (1971).

The air temperature data were used to calculate the potential evaporation using the method of HARGREAVES \& SAMANI (1985) for time intervals of 10 days for each setting of air temperature. The WRSI values were determined with frequency of occurrence of $80 \%$ and classified into three qualitative classes: (i) WRSI $\geq 0.50$ (low climatic risk), (ii) $0.40 \leq \mathrm{WRSI}<$ 0.50 (mean climate risk) and (iii) WRSI $<0.40$ (high climatic risk). For sites with missing or incomplete air temperature data it was used a polynomial model in terms of geographical coordinates and temperature anomalies of the sea surface. The details for the use of this model can be found in the Estima_T computer program (CAVALCANTI et al. 2006), as well as their theoretical validation in SILVA et al. (2006).

\section{RESULTS AND DISCUSSION}

The areas with high climatic risk for maize crop are growing with the increasing of air temperature, while those with low risk are decreasing in all months of maize crop (NovemberMay) in the Northeastern of Brazil (Table 1). The medium climatic risk is increasing in the months of November and December and decreasing in the remaining months of the cultivation of this cereal. In the second ten days of November, the areas with high climatic risk increases $90,934 \mathrm{~km}^{2}$ between the current weather conditions (CWC) and the scenario of $5^{\circ} \mathrm{C}$. The low climatic risk decreased $82.5 \%$ between the CWC and the scenario of $5^{\circ} \mathrm{C}$. In all three scenarios of air warming, the areas with medium climatic risk were always higher than those with low risk and lower than those with high risk. However, in CWC areas with low climatic risk were higher than those with medium climatic risk, except in the months of February and April. In this line of research, CAMPOS et al. (2010) observed that the increase in air temperature causes an increase in areas with medium and high climatic risks and consequently a reduction in areas with low climatic risks in all seasons of growth of cowpea in the state of Paraíba.

The high climatic risk of maize crop cultivated in the second ten days of December in the Northeastern of Brazil increased $19.7 \%$ between the CWC and the scenario of $5^{\circ} \mathrm{C}$. In these ten days, the high climatic risk in CWC occupied $60.3 \%$ of the total area of the Northeastern of Brazil, whereas in the preceding ten days the climatic risk was $66.3 \%$ of that area. The agricultural area with low climatic risk of maize in December, when compared with that of November, presented an increase of $4,409 \mathrm{~km}^{2}$. The low climatic risk for maize crop that month decreased $55.5 \%$ between the CWC and the scenario of $5 \%$. Some restrictions related to the physiological characteristics of the culture for sensibility to high temperatures can also cause a reduction in areas with medium and low climatic risks, because one of the major environmental factors that interfere with the growth and development of crops is the air temperature (SILVA et al., 2010a). 
TABLE 1. Agricultural area $\left(\mathrm{km}^{2}\right)$ of maize cultivated in the Northeastern of Brazil with low, medium and high climatic risks under the normal climatic conditions (NCC) and scenarios A (warming of $1.5^{\circ} \mathrm{C}$ ), B (warming of $3.0^{\circ} \mathrm{C}$ ) and $\mathrm{C}$ (warming of $5.0^{\circ} \mathrm{C}$ ) from November to May.

\begin{tabular}{|c|c|c|c|c|}
\hline Climatic Risk & CWC & $1,5^{\circ} \mathrm{C}$ & $3,0^{\circ} \mathrm{C}$ & $5,0^{\circ} \mathrm{C}$ \\
\hline \multicolumn{5}{|c|}{ November - Area in $\mathrm{km}^{2}$} \\
\hline High & $1,033,752$ & $1,074,898$ & $1,101,196$ & $1,124,686$ \\
\hline Medium & 191,112 & 279,898 & 336,628 & 375,639 \\
\hline Low & 334,045 & 204,113 & 121,085 & 58,585 \\
\hline \multicolumn{5}{|c|}{ December - Area in $\mathrm{km}^{2}$} \\
\hline High & 939,420 & $1,014,493$ & $1,074,806$ & $1,124,231$ \\
\hline Medium & 281,035 & 295,030 & 293,555 & 284,174 \\
\hline Low & 338,454 & 249,387 & 190,549 & 150,505 \\
\hline \multicolumn{5}{|c|}{ January - Area in $\mathrm{km}^{2}$} \\
\hline High & 829,565 & 906,928 & 983,004 & $1,048,187$ \\
\hline Medium & 332,900 & 343,608 & 301,143 & 269,873 \\
\hline Low & 396,444 & 308,374 & 274,763 & 240,849 \\
\hline \multicolumn{5}{|c|}{ February - Area in $\mathrm{km}^{2}$} \\
\hline High & 976,991 & $1,106,624$ & $1,193,828$ & $1,255,503$ \\
\hline Medium & 342,378 & 273,275 & 221,368 & 182,260 \\
\hline Low & 239,541 & 179,010 & 143,713 & 121,147 \\
\hline \multicolumn{5}{|c|}{ March - Area in $\mathrm{km}^{2}$} \\
\hline High & $1,295,705$ & $1,349,142$ & $1,396,989$ & $1,431,674$ \\
\hline Medium & 133,918 & 117,660 & 103,601 & 93,613 \\
\hline Low & 129,287 & 92,108 & 58,319 & 33,622 \\
\hline \multicolumn{5}{|c|}{ April - Area in $\mathrm{km}^{2}$} \\
\hline High & $1,289,634$ & $1,340,495$ & $1,378,402$ & $1,426,694$ \\
\hline Medium & 131,988 & 109,168 & 96,269 & 84,141 \\
\hline Low & 137,288 & 109,246 & 84,238 & 48,075 \\
\hline \multicolumn{5}{|c|}{ May - Area in $\mathrm{km}^{2}$} \\
\hline High & $1,343,135$ & $1,385,251$ & $1,425,745$ & $1,472,167$ \\
\hline Medium & 95,321 & 86,780 & 76,219 & 68,005 \\
\hline Low & 120,454 & 86,879 & 56,945 & 18,738 \\
\hline
\end{tabular}

The high climatic risk of maize during the month of January increased in $218,622 \mathrm{~km}^{2}$ in the scenario of $5^{\circ} \mathrm{C}$. As in December, the area with this climatic risk in CWC decreased from the previous month. This may be associated with the incidence of upper air cyclonic vortices that time of year in the coastal region. In February, the areas with medium and high climatic risks return to increase in the CWC; consequently, areas with low climatic risks also increase, considering that the main mechanism that produces rains in Northeastern of Brazil is the intertropical convergence zone (ITCZ), which has a higher incidence frequency in the first months of the year (SILVA, 2004).

The high climatic risk for maize crop in the first ten days of March increased from $83.1 \%$ to $91.8 \%$ in the $\mathrm{CWC}$ of every area of Northeastern of Brazil in the scenario of $5^{\circ} \mathrm{C}$. This increase is accompanied by decreases of low and medium climatic risks, which were, respectively, $30 \%$ and $73.9 \%$ between the CWC and the scenario of $5^{\circ} \mathrm{C}$. SILVA et al. (2010a) found that there are significant differences between agricultural areas cultivated in dryland farming with cowpea in Northeastern of Brazil in the three warming scenarios $\left(1,5^{\circ} \mathrm{C}, 3^{\circ} \mathrm{C}\right.$ and $5^{\circ} \mathrm{C}$ ) and the current weather conditions. In warming scenarios, the period of growth and productivity must be drastically affected as a result of the reduction in the area suitable for cultivation of this crop. Moreover, the impacts of climate change are highly variable in space 
and time due to variability in air temperature, precipitation, soil and vegetation. The results presented here indicate that the agricultural activity in the region studied is very dependent on the variation of air temperature and consequently of rainfall. The high climatic risk to the maize crop in the first ten days of April is very high in all climate scenarios, whose area ranged from $85.6 \%$ to $95.1 \%$ in the $\mathrm{CWC}$ in the warming scenario of $5^{\circ} \mathrm{C}$ of the total area of the Northeastern of Brazil. This difference corresponds to $137,050 \mathrm{~km}^{2}$, while the medium and low climatic risks decreased $47,847 \mathrm{~km}^{2}$ and $89,213 \mathrm{~km}^{2}$, respectively. The lowest reduction of arable land with maize in the region with low climatic risk was in April (64.98\%) despite high values of the areas with high climatic risk in CWC and the air warming scenarios analyzed in this study.

In the second ten days of May, even in the CWC, the high risk for growing maize is even higher, reaching $86.12 \%$ of the entire area of Northeastern of Brazil, whereas in the climate scenarios of $1.5^{\circ} \mathrm{C}, 3.0^{\circ} \mathrm{C}$ and $5.0^{\circ} \mathrm{C}$, this climatic risk represents $88.7 \%, 91.5 \%$ and $94.4 \%$ respectively of the total area of the region. The results also indicate that the cultivation of maize in the northeast during this time of the year is entirely unfeasible under the economic point of view. Variations of climate risks are associated with the irregularity of rainfall in that region for the cultivation of maize, because the systems that operate during the studied periods have large temporal and spatial variability (SILVA, 2004). Even taking the most optimistic scenarios for the planting of maize, it still observed large reduction of the agricultural area in the region, which results in a very significant negative impact to its economy. The reason is that maize cultivation also has great importance in family farming and agribusiness in the studied region. From the standpoint of food security, reduction of agricultural area has a high negative impact on the region due to the fact that maize is the staple food for the majority of the rural population in Northeastern of Brazil.

The air temperature significantly affects the phenology, the leaf expansion, the biomass production and the assimilate partitioning in different parts of the plant; making this crop have an ideal range for its development. Changes in climatic risks may be associated with irregular rainfall in Northeastern of Brazil because the weather systems that operate in the studied period vary in time and space (SILVA et al., 2011). Even considering the CWC, there is still a reduction in the agricultural field by varying the planting date. This also results in a very significant negative impact to the region, due to the fact that maize cultivation in dryland systems present great importance in family farming and agribusiness in Northeast of Brazil.

\section{CONCLUSIONS}

1. The increasing in air temperature significantly affects the availability of arable land for maize in Northeastern of Brazil. The duration of the growing season and productivity are drastically reduced;

2. The sowing season of maize crop from January to March is less affected by air warming scenarios than the sowing in November and December or April and May.

3. The medium climatic risk remains practically unchanged within the warming scenarios for maize, but the most appropriate time for its cultivation in Northeastern of Brazil is the second ten days of January.

4. The cultivation of maize in the Northeastern of Brazil during the second ten days of May is completely impractical from the economic point of view.

\section{ACKNOWLEDGMENTS}

The authors thank the National Council for Scientific and Technological Development (CNPq) for funding the project 481352/2008-2. 


\section{REFERENCES}

ASSAD, E.D.; PINTO, H.S.; ZULLA JUNIOR, J.; ÁVILA, A.M.H. Impacto das mudanças climáticas no zoneamento agroclimático do café no Brasil. Pesquisa Agropecuária Brasileira, Brasília, v.39, n.11, p.1057-1064, 2004.

BARON, C.; SULTAN, B.; BALME, M.; SARR, B.; TRAORÉ, S.; LEBEL, T.; JANICOT, S. DINGKUHN, M. From GCM grid cell to agricultural plot: scale issues affecting modeling of climate impact. Philosophical Transactions of the Royal Society of London. Series B, Biological Sciences, London, v.360, n, 1, p.2095-2108, 2005.

CAMPOS, J.H.B.C.; SILVA, M.T.; SILVA, V.P.R. Impacto do aquecimento global no cultivo do feijão-caupi, no Estado da Paraíba. Revista. Brasileira de Engenharia Agrícola e Ambiental, Campina Grande, v.14, n.4, p.396-404, 2010.

CAVALCANTI, E.P.; SILVA, V.P.R.; SOUSA, F.A.S. Programa computacional para a estimativa da temperatura do ar para a Região Nordeste do Brasil. Revista Brasileira de Engenharia Agrícola e Ambiental, Campina Grande, v.10, n.1, p.140-147, 2006.

COMPANHIA NACIONAL DE ABASTECIMENTO - CONAB. Avaliação da safra agrícola 2004/2005: sexto levantamento agosto de 2005. Disponível em: http://www.conab.gov.br. Acesso em: 10 abr. 2008.

EAGLEMAN, A.M. An experimentally derived model for actual evapotranspiration. Agricultural Meteorology, Amsterdam, v.8, n.1, p.385-409, 1971.

FAGUNDES, J.D.; STRECK, N.A.; BISOGNIN, D.A.; SCHWANTES, A.P.; ALBERTO, C.M. Produtividade simulada de tubérculos de batata em cenários de mudanças climáticas. Pesquisa Agropecuária Brasileira, Brasília, v.45, n.4, p.351-360, 2010.

GHINI, R.; HAMADA, E.; PEDRO JÚNIOR, M.J.; MARENGO, J.A.; GONÇALVES, R.R.V. Risk analysis of climate change on coffee nematodes and leaf miner in Brazil. Pesquisa Agropecuária Brasileira, Brasília, v.43, n.2, p.187-194, 2008.

GONDIM, R.S.; CASTRO, M.A.H.; EVANGELISTA, S.R.M.; TEIXEIRA, A.S. FUCK JÚNIOR, S.C.F. Mudanças climáticas e impactos na necessidade hídrica das culturas perenes na Bacia do Jaguaribe, no Estado do Ceará. Pesquisa Agropecuária Brasileira, Brasília, v.43, n.12, p.16571664, 2008.

HARGREAVES, G.H., SAMANI, Z.A. Reference crop evapotranspiration from temperature. Transaction of the ASAE, St. Joseph, v.2, n.1, p.96-99, 1985.

INTERGOVERNMENTAL PANEL ON CLIMATE CHANGE. Climate change 2007: the physical science basis: contribution of Working Group I to the Fourth Assessment Report of the Intergovernmental Panel on Climate Change. Cambridge: IPCC, 2007. 989p.

KOURESSY, M.; DINGKUHN, M.; VAKSMANN, M.; HEINEMANN, A.B. Adaptation to diverse semi-arid environments of sorghum genotypes having different plant type and sensitivity to photoperiod. Agricultural and Forest Meteorology, Amsterdam, v.148, n.1, p.357-371, 2008.

LAGO, I.; STRECK, N.A.; ALBERTO, C.M.; OLIVEIRA, F.B.; PAULA, G.M. Impact of increasing mean air temperature on the development of rice and red rice. Pesquisa Agropecuária Brasileira, Brasília, v.43, n.11, p.1441-1448, 2008.

SALAZAR, D.R.; STABILE, S.S.; GUIMARÃES, P.S.; PATERNIANI, M.E.A.G.; SANTOS, M.V.; SILVA, L.F.P. Valor nutritivo do colmo de híbridos de milho colhidos em três estádios de maturidade. Pesquisa Agropecuária Brasileira, Brasília, v.45, n.7, p.758-766, 2010.

SANTOS, D.N.; SILVA, V.P.R.; SOUSA, F.A.S.; SILVA, R.A. Estudo de alguns cenários climáticos para o Nordeste do Brasil. Revista Brasileira de Engenharia Agrícola e Ambiental, Campina Grande, v.14, n.5, p.492-500, 2010. 
SILVA, V.P.R. On climate variability in Northeast of Brazil. Journal of Arid Environments, London, v.58, n.1, p.575-596, 2004.

SILVA, V.P.R.; SOUSA, F.A.S.; CAVALCANTI, E.P.; SOUZA, E.P.; SILVA, B.B.

Teleconnections between sea-surface temperature anomalies and air temperature in northeast Brazil. Journal of Atmospheric and Terrestrial Physics, Oxford, v.68, n.1, p.781-792, 2006.

SILVA, V.P.R.; CAMPOS, J.H.B.C.; SILVA, M.T.; AZEVEDO, P.V. Impact of global warming on cowpea bean cultivation in northeastern Brazil. Agricultural Water Management, Amsterdam, v.97, n.1, p.1760-1768, 2010a.

SILVA, V.P.R.; AZEVEDO, P.V.; BRITO, R.S.; CAMPOS, J.B.C. Evaluating the urban climate of a typically tropical city of northeastern Brazil. Environmental Monitoring and Assessment, Dordrecht, v.161, n.1, p.45-59, 2010 b.

SILVA, V.P.P.; SILVA, R.A.; CAVALCANTI, E.P.; BRAGA, C.C.; AZEVEDO, P.V.; SINGH, V.P.; PEREIRA, E.R.R. Trends in solar radiation in NCEP/NCAR database and measurements in northeastern Brazil. Solar Energy, Kidlinton, v.84, n.1, p.1852-1862, 2010c.

SILVA, V.P.R.; PEREIRA, E.R.R.; AZEVEDO, P.V.; SOUSA, I.F. Análise da pluviometria e dias chuvosos na região Nordeste do Brasil. Revista Brasileira de Engenharia Agrícola e Ambiental, Campina grande, v.15, n.2, p.131-138, 2011.

STRECK, N.A.; ALBERTO, C.M. Estudo numérico do impacto da mudança climática sobre o rendimento de trigo, soja e milho. Pesquisa Agropecuária Brasileira, Brasília, v.41, n.9, p.13511359, 2006. 